\title{
Moringa oleifera: A COST EFFECTIVE COAGULANT FOR DYE DEGRADATION
}

\author{
Mahalakshmi Mathivanan* and Saranaathan S. E. \\ School of Civil Engineering, SASTRA University, Thanjavur-613401, Tamilnadu, India \\ *E-mail : mahalakshmi@ civil.sastra.edu
}

\begin{abstract}
The purpose of the work is to understand the effect of the ratio of Moringa olifera Seed powder and $\mathrm{NaCl}$, current density, initial $\mathrm{pH}$ and agitation speed on color removal efficiency as well as COD removal from synthetic textile wastewater in the electro-coagulation technique using iron and steel electrodes. The suitable conditions for reducing color as well as COD were as follows: ratio of Moringa Olifera Seed powder and $\mathrm{NaCl}=1: 1.5$; current density $=15$ $\mathrm{mA} / \mathrm{cm} 2$; initial $\mathrm{pH}=7-8$; agitation speed $=400 \mathrm{rpm}$. The efficiency of color reduction and COD reduction under these conditions were found to be $60 \%$ and $55 \%$ respectively. This investigation proved that the electro-coagulation technique is a suitable method for the treatment of dye industry effluents for the purpose of reuse.

Keywords: Dye degradation, Moringa oleifera, Methylene blue dye, Electrochemical coagulation, COD removal.

(c) RASĀYAN. All rights reserved
\end{abstract}

\section{INTRODUCTION}

Color removal is one of the demanding environmental harms in close proximity to fabric factories. For giving the pigments to the ending produce, the manufacturers of textile, leather and paper \& pulp are by means of different stains. Dye effluent leaving the textile industry has been considered as a pollutant owing to its chemical composition and capacity. ${ }^{1}$ The textile effluent could be subjected to dye removal treatment to prevent the living organisms from toxicity effects. Discarding of dye sewage with essential treatment is a great task. ${ }^{2}$ Methylene blue is extensively used as a coloring substance in pulp, paper, textile, and wood industries. ${ }^{3}$ Dye effluent discharged from textile industry is treated by the adsorption ${ }^{4-6}$ biological method by the action of microbes under aerobic or anaerobic conditions and chemical treatment. ${ }^{7-9}$ The treatment of dye effluent is considered important due to the high concentration of pollutants, suspended solids, chemical oxidation demand and biological oxygen demand. ${ }^{10}$ Electrocoagulation is an efficient technique to eradicate color as well as COD from wastewater. ${ }^{11}$ Several researchers have proposed electro-coagulation method for the removal of pollutant as color from industrial effluent using sodium chloride as supporting electrolyte. It was investigated the decolorization of reactive dye effluent by electro-coagulation method using aluminum electrodes and the percentage color removal was found to be 97.38. ${ }^{12}$ Also, the existing work was reported that the decolorization of textile effluent by electrocoagulation (EC) method using aluminum electrodes and the color removal was obtained to be $96.5 \% .^{13}$ Other than textile effluent, electrochemical coagulation method was effectively employed for the removal of color from distillery spent wash $^{14}$, egg processing effluent ${ }^{15}$ and pulp \& paper industry bleaching effluent. ${ }^{16}$ The decolorization efficiency is highly influenced by the type of electrodes used, suitable coagulant and processing conditions namely current density and agitation speed $^{17}$. Alum, chloride salts namely ferric chloride, aluminum chloride, sodium chloride, ferric chloride are extensively used in electro-coagulation process to treat various effluents. ${ }^{10,17,18}$ In order to reduce the economy of process considerably, it is necessary to design a cost effective as well as an eco-friendly coagulant for electro-coagulation process.

In the present study, cost effective and vegetative coagulant, Moringa oleifera seed powder was employed to reduce color as well as COD from synthetic dye solution. The factors such as the ratio of Moringa Olifera Seed powder and $\mathrm{NaCl}$, current density, initial $\mathrm{pH}$ and agitation speed on color removal efficiency as well as COD removal was studied. 


\section{Batch Electro-Coagulation Studies}

\section{EXPERIMENTAL}

The matured drumsticks were collected from local villages, Thanjavur district, Tamilnadu, India. The seeds were carefully taken from matured drumsticks, dried and crushed using an electric mixer. An appropriate proportion of crushed drum stick seed and sodium chloride was considered as a coagulant for the removal of color from aqueous dye solution by electro-chemical coagulation method. The synthetic dye solution was prepared from methylene blue. Five hundred $\mathrm{ml}$ of synthetic dye solution was taken in an electro chemical reactor in which electrodes were placed vertically with $7 \mathrm{~cm}$ internal spacing. Iron and stainless steel were used as anode and cathode respectively. The dimensions of the electrode are 14 $\mathrm{cm}$ length and $6 \mathrm{~cm}$ width. The reactor was kept in a magnetic stirrer to get uniform mixing of effluent. Based upon the exposure of electrode area in the effluent present in the reactor, the current intensity $\left(\mathrm{mA} / \mathrm{cm}^{2}\right)$ was selected with fixed current $(0.5 \mathrm{~A})$. After electro-coagulation process, the sample was filtered through Whatmann filter paper. Finally, the color intensity of treated dye effluent was determined by UV-Vis spectrophotometer (Elico SL-164) with an optical density of $662 \mathrm{~nm} .{ }^{19}$ The color intensity of the aqueous dye solution was expressed by milligram $(\mathrm{mg})$ of dye per liter of solution. The chemical oxygen demand, COD was determined as per the method described by APHA. ${ }^{20}$ The different factors such as current density, $\mathrm{pH}$, agitation speed, the ratio of $\mathrm{NaCl}$ and Moringa Oleifera seed powder on \% color removal and \% COD removal were studied.

\section{Effect of ratio of Moringa Olifera Seed powder and $\mathrm{NaCl}$}

Figure-1 explains the effect of the ratio of Moringa Olifera Seed powder and $\mathrm{NaCl}$ on color and COD removal efficiency. The potential increase in color removal rate $(35 \%$ to $60 \%)$ and COD removal rate ( $25 \%$ to $50 \%$ ) was achieved as the ratio of seed powder to $\mathrm{NaCl}$ concentration increased from 1: 0.5 to 1: 2.5. The increase in conductivity was due to the formation of $\mathrm{OCl}^{-}$from $\mathrm{Cl}^{-}$containing effluent. The significant degree of $\mathrm{COD}$ has been removed with the presence of $\mathrm{NaCl}$ and there was no considerable change on $\mathrm{COD}$ removal after seed powder and $\mathrm{NaCl}$ ratio of 1: 1.5 . Sodium chloride is used as an electrolyte to enhance the electrical conductivity due to the formation of $\left(\mathrm{OCl}^{-}\right)$ions during an electrochemical process. Low $\mathrm{NaCl}$ concentration results in poor ionization, where as high concentration leads to scale deposition on electrodes. The adequate composition of sodium chloride should be used in electrochemical coagulation. ${ }^{21}$ The addition of $\mathrm{NaCl}$ decreases the specific energy consumption due to decreased total resistance in the solution and voltage by increasing ionic strength with constant current density.

\section{Effect of current density}

Current density is a crucial parameter influencing electrochemical coagulation process. ${ }^{22,23}$ Figure-2 explains the effect of current density on the removal of color and COD. The color removal and COD degradation were significantly improved due to the density of gas bubbles. ${ }^{24}$ The removal of color and COD were improved with an increase in current density till $80 \mathrm{~min}$. There is no significant effect observed on reduction in percentage color and COD removal even if the increase in current density above $20 \mathrm{~mA} / \mathrm{cm}^{2}$. The electrical potential was increased due to the development of hypochlorite ion or chloride ion with an increase in current density. Therefore, the rate of transfer of pollutant removal was rapid due to the formation of chloride or hypochlorite ion. ${ }^{25}$ Similarly, Sridhar et al., 2011 reported maximum removal of color as well as COD from bleaching effluent (paper and pulp industry) with a current density of $20 \mathrm{~mA} / \mathrm{cm}^{2} .{ }^{16}$

\section{Effect of initial pH}

The medium $\mathrm{pH}$ is an important factor influencing the performance of Electro coagulation process. When an electrical potential is applied during the process, an oxidation reaction takes place in the iron sacrificial electrode in the presence of alkali and acid medium as given below. 
For acidic condition:

$\mathrm{Fe} \rightarrow \mathrm{Fe}^{3+}+3 \mathrm{e}^{-}$

$\mathrm{Fe}^{3+}+3 \mathrm{H}_{2} \mathrm{O} \rightarrow \mathrm{Fe}(\mathrm{OH})_{3}+3 \mathrm{H}^{+}$

For alkali condition:

$\mathrm{Fe} \rightarrow \mathrm{Fe}^{3+}+3 \mathrm{e}^{-}$

$3 \mathrm{e}^{-}+3 \mathrm{H}_{2} \mathrm{O} \rightarrow 1.5 \mathrm{H}_{2(\mathrm{~g})}+3 \mathrm{OH}^{-}$

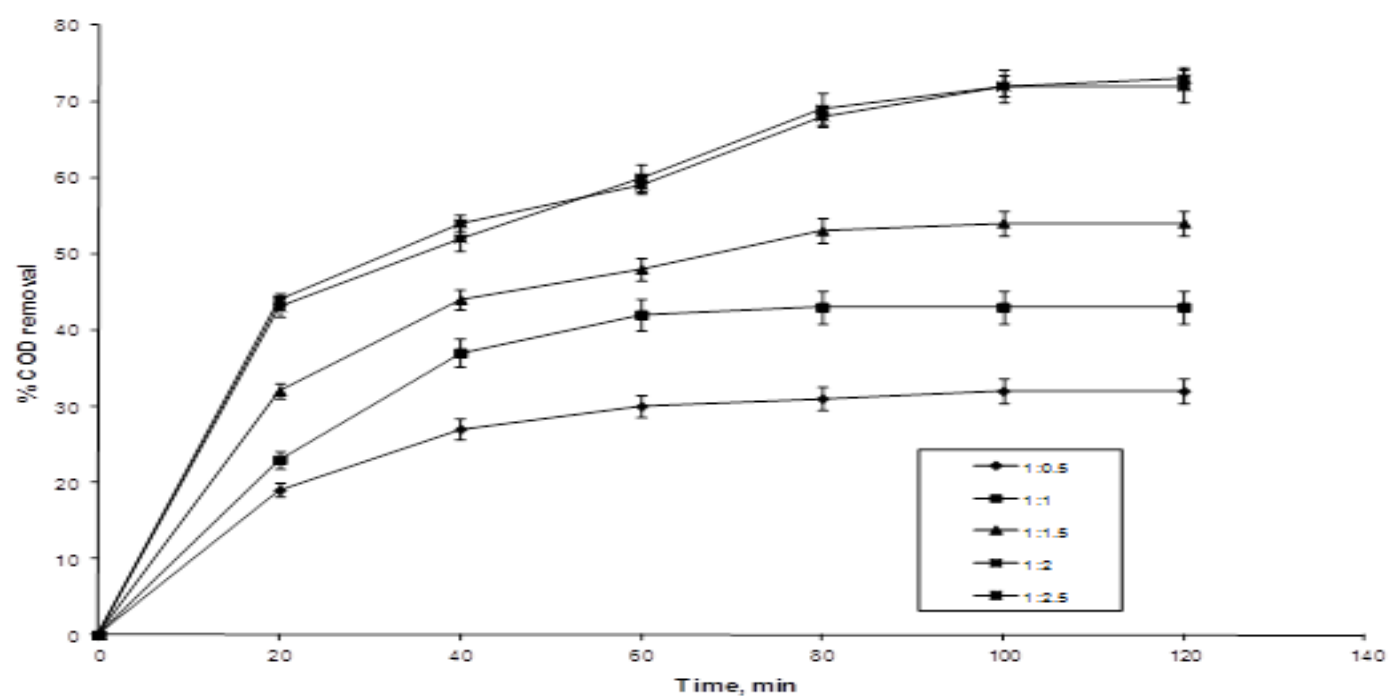

(a)

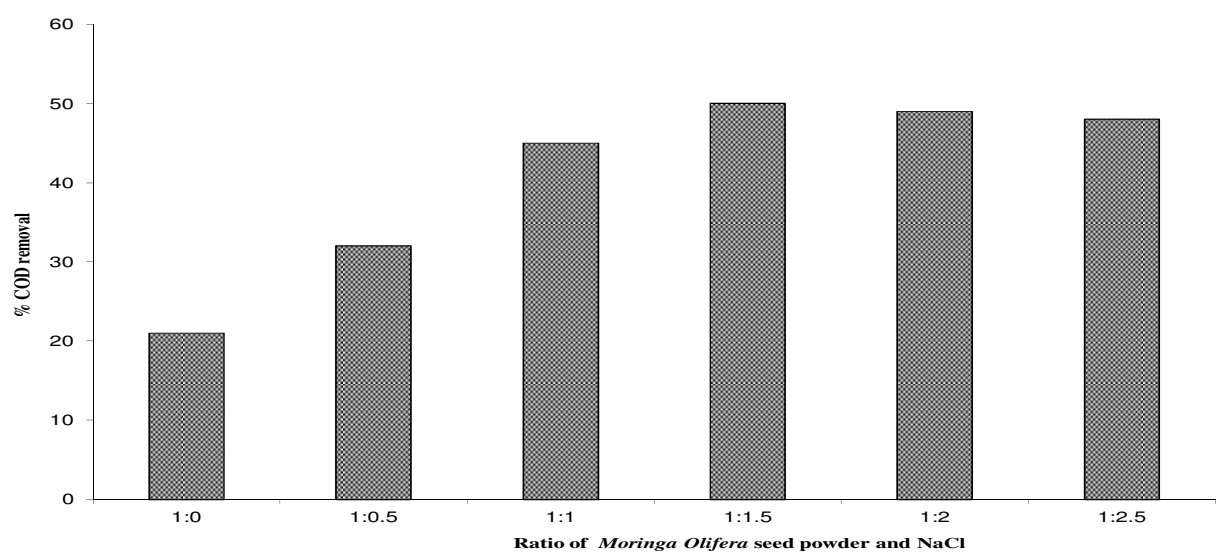

(b)

Fig.-1: Effect of Moringa Olifera Seed powder and $\mathrm{NaCl}$ concentration on (a) \% color removal (b) \% COD removal $\left(\mathrm{pH}: 7\right.$; Methylene blue dye concentration $=100 \mathrm{mg} / \mathrm{dm}^{3} ; \mathrm{T}=30^{\circ} \mathrm{C}$, current density $=10 \mathrm{~mA} / \mathrm{cm}^{2}$, volume of solution $=500 \mathrm{ml}$ )

The effect of medium $\mathrm{pH}$ on percentage removal of color and COD were depicted in Fig.-3. It is clearly noted that both color removal and COD removal efficiency is greatly improved until $\mathrm{pH} 7$. The formation of amorphous $\mathrm{Fe}(\mathrm{OH})_{3}$ on electrode surface area favors the rapid adsorption rate of soluble organic substances there by reducing of the colloidal compounds. As a result, a high degree of color and COD 
RASĀYAN J. Chem.

Vol. 10 | No. 4 |1097-1103 | October - December | 2017

removal was achieved at $\mathrm{pH}$ 7. The increase in medium $\mathrm{pH}$ above 7 significantly reduces the color removal as well as $\mathrm{COD}$ removal efficiencies due to the formation of $\mathrm{Fe}(\mathrm{OH})_{4}{ }^{-26}$

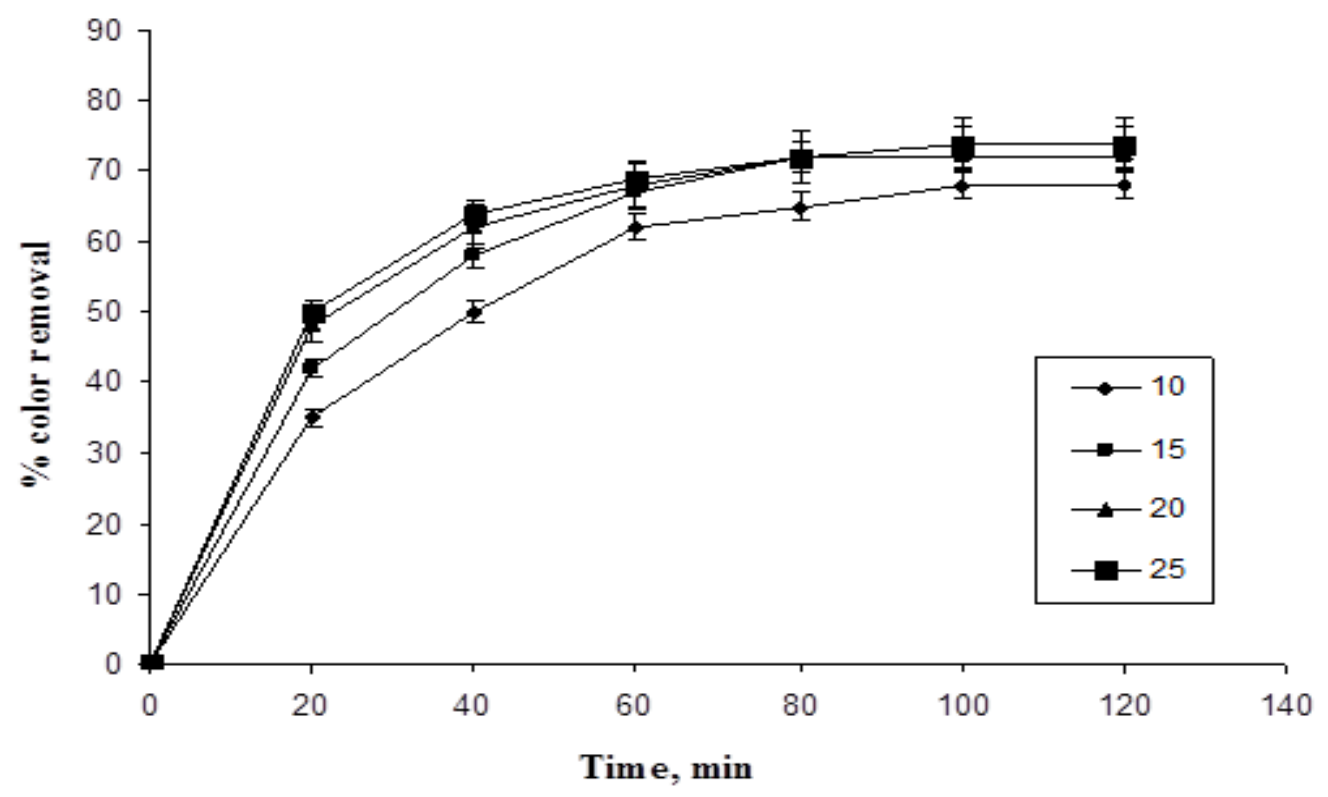

(a)

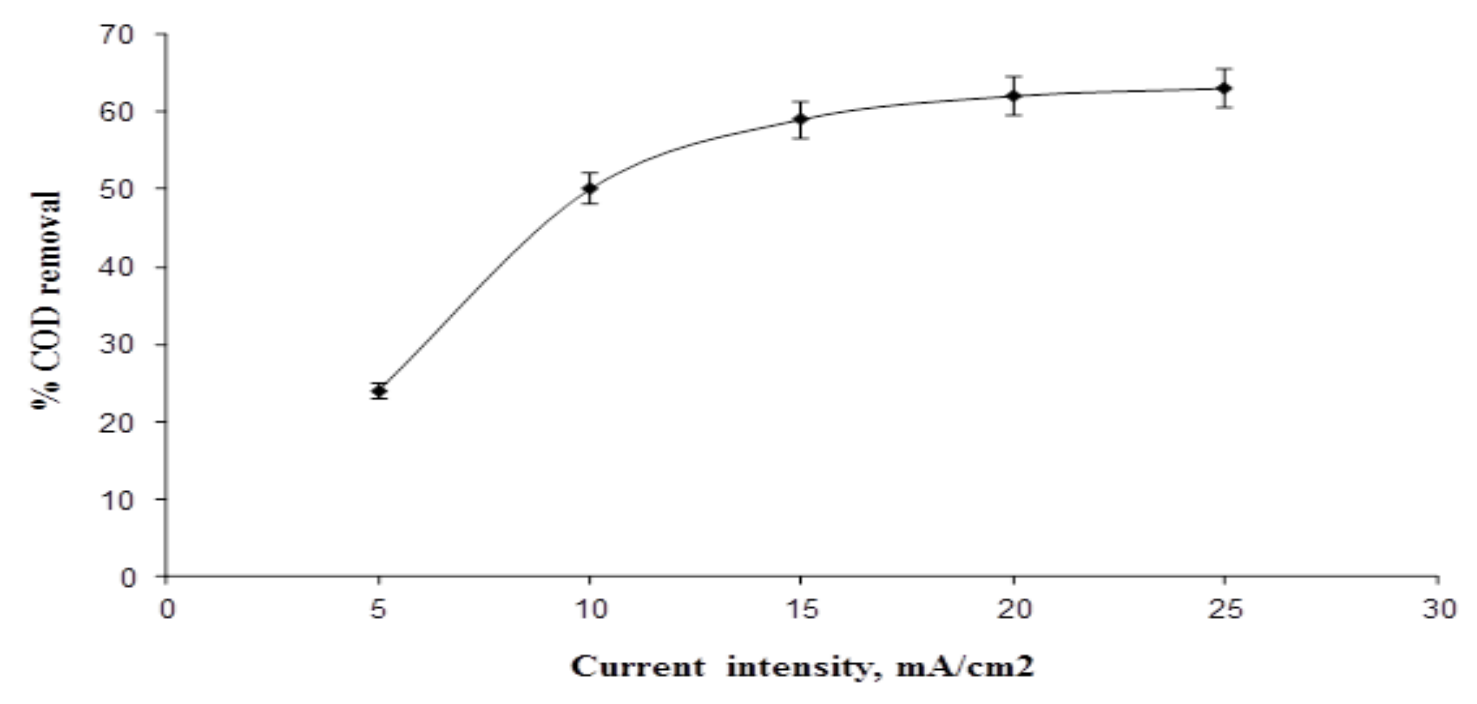

(b)

Fig.-2: Effect of current density on (a) \% color removal (b) \% COD removal (Methylene blue dye concentration $=$ $100 \mathrm{mg} / \mathrm{dm}^{3} ; \mathrm{T}=30^{\circ} \mathrm{C}, \mathrm{NaCl}=1.5 \mathrm{~g} / \mathrm{dm}^{3}$, volume of solution $=500 \mathrm{ml}$ )

\section{Effect of agitation speed}

Figure-4 explains the influence of agitation speed on color removal and COD removal rate. Increase in color removal rate (45\% to $60 \%$ ) and COD removal rate (26\% to $48 \%$ ) were observed by increasing agitation speed from 50 to $400 \mathrm{rpm}$ owing to the development of the turbulent condition. The pollutant removal rate was drastically improved due to the reduction of boundary layer thickness near electrode surface area. Increase in agitation speed leads turbulence in the solution. The formation of turbulence improves the release of gas bubbles near to the surface of the electrode by decreasing cell density ${ }^{16}$. 
RASĀYAN J. Chem.

Vol. 10 | No. 4 |1097-1103 | October - December | 2017

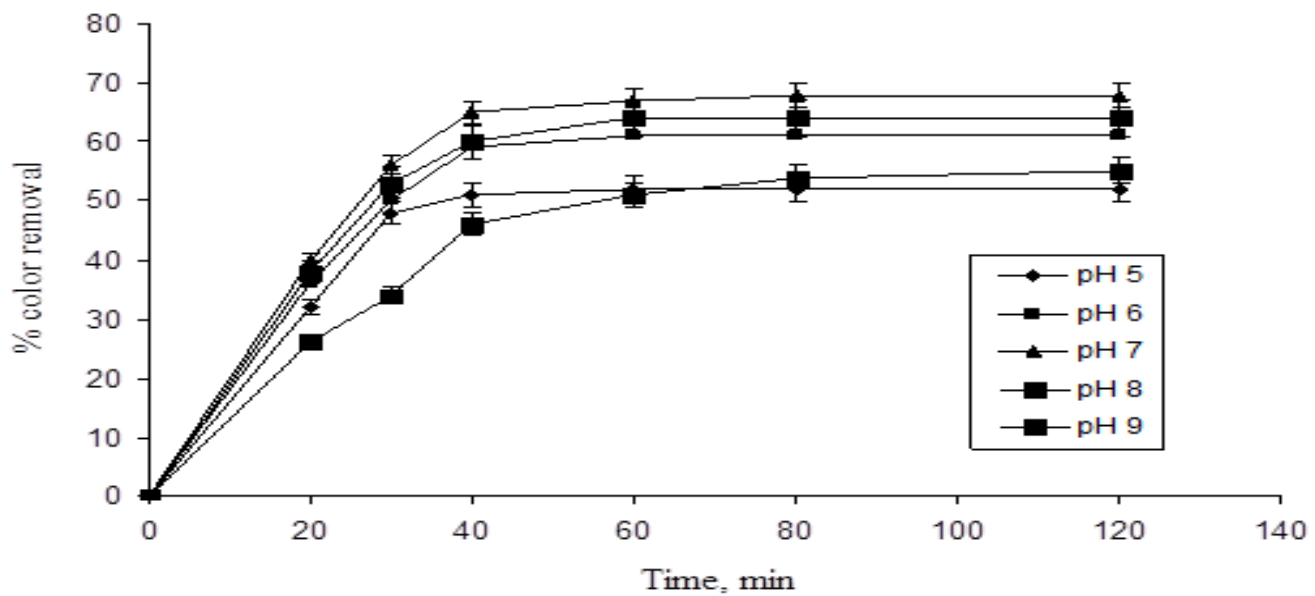

(a)

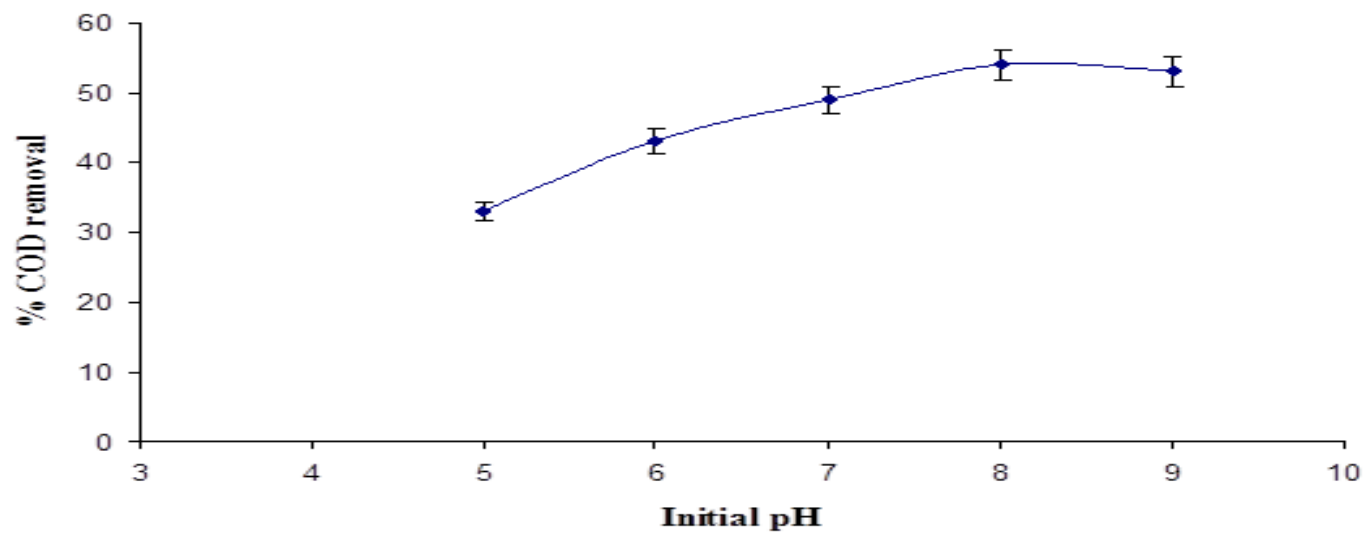

(b)

Fig.-3: Effect of initial pH on (a) \% colour removal (b) \% COD removal (Methylene blue dye concentration $=100$ $\mathrm{mg} / \mathrm{dm}^{3} ; \mathrm{T}=30^{\circ} \mathrm{C}$, current density $\left.=15 \mathrm{~mA} / \mathrm{cm}^{3}\right) ; \mathrm{NaCl}=1.5 \mathrm{~g} / \mathrm{dm}^{3}$, volume of solution $=500 \mathrm{ml}$ )

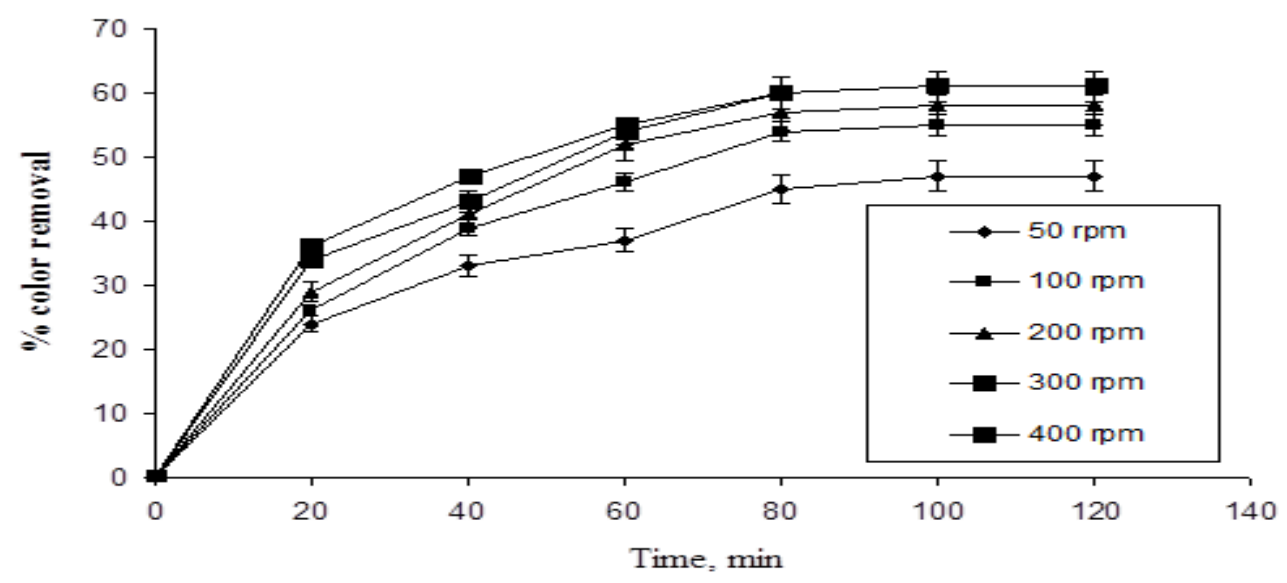

(a) 
RASĀYAN $J$. Chem.

Vol. 10 | No. 4 |1097-1103 | October - December | 2017

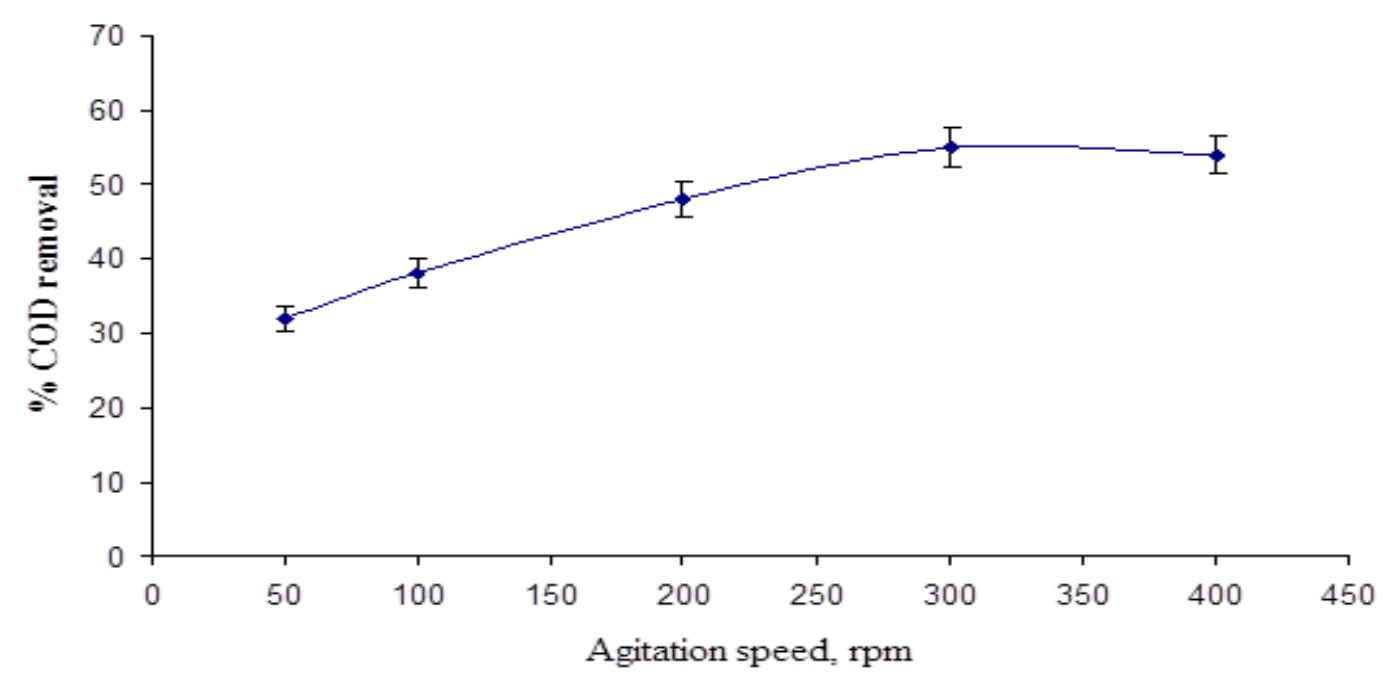

(b)

Fig.-4: Effect of initial dye concentration on (a) \% colour removal (b) \% COD removal (Methylene blue dye concentration $=100 \mathrm{mg} / \mathrm{dm}^{3} ; \mathrm{T}=30^{\circ} \mathrm{C}$, current density $=15 \mathrm{~mA} / \mathrm{cm}^{3} ; \mathrm{NaCl}=1.5 \mathrm{~g} / \mathrm{dm}^{3} ;$ volume of solution $=500 \mathrm{ml}$ )

\section{REFERENCES}

1. A. Jumasiah , T. G. Chuah, J. Gimbon, T. S. Y. Choong and I. Azni, Desalination, 186(1-3), 57 (2005).

2. P. Saha and S. Datta, Desalination and Water Treatment, 12, 219 (2009).

3. M. Mahalakshmi and S. E. Saranaathan, Journal of Chemical and Pharmaceutical Research, 7(1), 817 (2015).

4. S. Ramesh, J. S. Sudarsan and M. Jothilingam, Rasayan J. Chem., 9, 325 (2016).

5. K. Venkata Ramana, K. Swarna Latha, K. Ravindranath and B. Hari Babu, Rasayan J. Chem., 10, 349 (2017).

6. C. Sumithra and S. Karthikeyan, Rasayan J. Chem., 7, 149 (2014).

7. Z. Bekcki, S. Yoldas, L. Cavas, Journal of Hazardous Material, 161, 1454 (2009).

8. R. Gong, Y. Sun, J. Chen, H. Liu and C. Yang, Dyes Pigments, 67, 175 (2005).

9. R. Gong, Y. Jin, Y. Chen and J. Hu. Sun, Dyes Pigments, 73, 332 (2006).

10. D. K. Singh and B. Srivastava, Indian J. Environ. Health, 41, 333 (1999).

11. G. Thompson, J. Swain, M. Kay and C. F. Forster, Bioresource Technology, 77, 275 (2001).

12. Z. El-Ashtoukhy, A. A. Mobarak and Y. O. Fouad, Int. J. Electrochem. Sci., 11, 1883 (2016).

13. A. S. Naje, S. Chelliapan, Z. Zakaria and Saad A. Abbas, Int. J. Electrochem. Sci., 10, 4495 (2015).

14. R. Krishna Prasad and S. N. Srivastava, Chemical Engineering Journal, 146, 22 (2009).

15. R. Sridhar, V. Sivakumar and J. Prakash Maran and K. Thirugnanasambandham, Int. J. Environ. Sci. Technol., 11, 1619 (2014).

16. R.Sridhar, V. Sivakumar, V. P. Immanuel and J. P. Maran, J. Hazard. Mater.,186, 1495 (2011).

17. P. A. Soloman, C. Ahmed Basha, M. Velan, N. Balasubramanian, P. Marimuthu, Sep. Purif. Technology, 69, 109 (2009).

18. U. D. Patel and S. Suresh, Sep. Purif. Technology, 61, 115 (2008).

19. R. Wang, C. L. Chen and J. S. Gratzl, Bioresour. Technology, 94, 267 (2004).

20. V. Ponnusami, R. Madhuram, V. Krithika and S. N. Srivastava, Chemical Engineering Journal, 140(1-3), 609 (2008).

21. I. Kabdaşlı, I. Arslan-Alaton, T. Olmez-Hancı and O. Tünay, Environmental Technology Reviews, 1, 2 (2012). 
RASĀYAN $J$. Chem.

Vol. 10 | No. 4 |1097-1103 | October - December | 2017

22. A. E. Greenberg, J. J. Connors, D. Jenkins and M. A. Franson, Standard Methods for the Examination of Water and Wastewater, American Public Health Association, Washington 15 ${ }^{\text {th }}$ edition, (1995).

23. S. Mahesh, B. Prasad, I. D. Mall and I. M. Mishra, Ind. Eng. Chem. Research, 45, 2830 (2006).

24. N. Adhoum, L. Monser, N. Bellakhal and J. E. Belgaied, J. Hazard. Mater, 112, 207 (2004).

25. M. Kobya, O. T. Can and M. Bayramoglu, J. Hazard. Mater, 100, 163 (2003).

26. M. Zaied and N. Bellakhal, J. Hazard. Mater, 163, 995 (2009).

[RJC-1865/2017] 